International Research Journal of Management, IT \& Social Sciences
Available online at https://sloap.org/journals/index.php/irjmis/
Vol. 6 No. 6, November 2019, pages: 43 49
ISSN: 2395-7492
https://doi.org/10.21744/irjmis.v6n6.755

\title{
Grand Investment of Tourism Sector Effort to Make Many Villas and Hotels for Expanding Work Opportunities on Budgeting
}

Ni Nyoman Sunariani ${ }^{a}$

A. A. Istri A. Maheswari ${ }^{\text {b }}$

A. A. Gde Putra Pemayun ${ }^{\text {c }}$

\section{Article history:}

Received: 18 May 2019

Accepted: 31 July 2019

Published: 27 September 2019

\section{Keywords:}

education;

expenditure;

grand investment;

job opportunities;

tourism sector;

\begin{abstract}
This research discussed grand investment tourism sector efforts to increase the number of villas and hotels to expand employment opportunities in the Subdistrict of Ubud Bali." affect the economic growth of a region. The main problem is how is the tourism sector's grand investment effort to increase the number of villas and hotels to expand employment opportunities in the Subdistrict of Ubud Bali? High levels of unemployment can increase the amount of crime and increase social unrest. If examined further, from an economic standpoint, if many foreign and local investments are realized then job opportunities are wide open for the people in the area and other regions so that people's income rises by itself. The government is trying to create vocational education that aims to produce a quality and superior workforce in all sectors. Investment activities are the use of a sum of money in the hope of obtaining benefits and can plan their financing and implementation as a unit of activity within a certain period of time. Expenditure on investment costs is done once and only produces benefits a few years later.
\end{abstract}

2395-7492@ Copyright 2019. The Author. This is an open-access article under the CC BY-SA license (https://creativecommons.org/licenses/by-sa/4.0/) All rights reserved.

\section{Author correspondence:}

Ni Nyoman Sunariani,

Universitas Pendidikan Nasional, Denpasar, Indonesia Ph.: +628124639246.

Email address: nyomansunariani@ymail.com

\section{Introduction}

Investment is the use of an amount of money in the hope of obtaining benefits and can plan its financing and implementation as a unit of activity within a certain period of time. Expenditure on investment costs is generally done once and only produces benefits a few years later (Kuntjjoro, 2011). Investment is needed for the development of the tourism sector and this requires a good information system about the supply of the sector which consists of elements of natural attraction, human creation and also demand, namely demand for tourism such as beautiful natural scenery,

a Universitas Pendidikan Nasional, Denpasar, Indonesia

${ }^{\text {b } U n i v e r s i t a s ~ P e n d i d i k a n ~ N a s i o n a l, ~ D e n p a s a r, ~ I n d o n e s i a ~}$

${ }^{\mathrm{c}}$ Universitas Pendidikan Nasional, Denpasar, Indonesia 
fresh air, light sun and others (Yahya, 2002). Tourism sector development is a process of change that covers all social systems, such as politics, economy, infrastructure, defense, education and technology, institutions, and culture (Alexander (1986) in Yunma 2006).

The population in Bali is uneven so that the density in several cities greatly influences development. With this population density, the competition to find employment is very difficult and lead to unemployment and poverty. Unemployment is a major problem in modern society. If the unemployment rate is high, resources will be wasted and people's income levels will decline. This situation created an economic downturn which also affected the emotions of the people of Sub-district of Ubud and uncontrolled social unrest. The main factors causing unemployment are people who are in the productive age/working age who are not working. One of the big problems in the Sub-district of Ubud Bali is the problem of unemployment, which is never resolved every year. The unemployment factor can vary in variety, and this should not be ignored by the government. Efforts to overcome unemployment is not merely a government obligation (Wisudawati \& Maheswari, 2018).

The entire community of Sub-district of Ubud Bali expected to participate in overcoming this problem. Without the cooperation of the government and the community it is impossible to overcome. Some of the common causes of unemployment in the Sub-district of Ubud Bali are low education. Low education can cause a person difficulty in finding work. Because all companies need a minimum of high school employees even Diploma and Bachelor degree. The solution to overcome unemployment is by opening up foreign and domestic investment especially in the tourism sector because investment in this sector produces more quickly compared to other sectors. Based on the above phenomena, it is interesting to study the findings. In this research the main issues can be formulated as follows:

1) How can Grand investment expand employment opportunities in the Sub-district of Ubud Bali?

2) How is the effort to print human resources with high competence in order to compete in the global era?

\section{Literature review}

Investment activities have been widely studied by local and foreign researchers. However, research on the tourism sector's Grand Investment effort to increase the number of Villas and Hotels is interesting to study because it has not been widely appointed as a research study.

Research from Laurensius Arliman (2018), with the title The Role of Investment in Tourism Economic Development Policy in the Province of West Sumatra. Tourism is a national priority in the 2015-2019 RPJM. Gradually from year to year in the 5-year period of the 2015-2019 RPJM, tourism development is prioritized and given its achievement targets. West Sumatra also supports tourism to support economic development. The formulation of the problems in this study are: 1) what is the role of investment in economic development in tourism in West Sumatra? 2) how is government support for economic development in tourism in West Sumatra? Legal research used in this study is normative legal research using the normative juridical approach. The results of this study explain that the role of investment in economic development in tourism is very important, especially to facilitate tourism development in West Sumatra. Government support for economic development in tourism in West Sumatra is marked by the development of tourism infrastructure, the construction of railroads as a mode of transportation and the provision of loans and the ease of granting permits in investing in West Sumatra by BKPM.

Furthermore, research from Syaeful Bakhri (2018), with the title Student Interest in Investing in the Capital Market. Referring to the Indonesian Central Securities Depository (KSEI) data, the number of Indonesian capital market investors as of March 2018 reached 1.21 million single investor identification (SID), up 36 percent from the realization of 2016 of 894,116 SID. A double-digit increase does not make the number of investors considered significant when compared to the total 260 million population of Indonesia. Students as agents of change have a very strategic role in disseminating information about investing in the capital market. This study aims to see the response and measure the interest of students of the Faculty of Sharia and Islamic Economics IAIN Sheikh Nurjati Cirebon in investing in the capital market. Some things that can be seen and affect students' interest in investing are investment benefits, valueadded investments, and economic conditions. The sample of this study was 96 students of the Sharia Faculty and Islamic economics of IAIN Sheikh Nurjati Cirebon (Amerta et al., 2018).

The results of this study indicate that there is no relationship between the benefits of investment with the interest in investing in students of IAIN Sheikh Nurjati Cirebon, as evidenced by the value $(\mathrm{p}=0.336>0.05)$. The analysis also illustrates that there is no relationship between value-added and investment interest in IAIN Sheikh Nurjati students in Cirebon, as evidenced by the value $(\mathrm{p}=0.574>0.05)$. Variable economic conditions of students with investment interest in IAIN Sheikh Nurjati students in Cirebon apparently also did not have a relationship, evidenced by the results $(\mathrm{p}=0.619>0.05)$. 
Investment for students is a learning process in order to prepare themselves in building economic life both personally and family. Efforts to increase continuous socialization must be carried out because after all the capital market is one of the doors for the learning process of students about economics and investment. From the two studies above, this research differs in terms of the location of the study, the variables used and the results of the discussion.

\section{Materials and Methods}

\subsection{Data Types and Sources}

The data used in this study are:

a) Primary data, i.e. data and information obtained directly from sources/respondents. This data was obtained by conducting interviews with the Staff of the Investment Coordinating Board of the Gianyar Regency of Bali. By using proportional sampling technique with a sample of 4 people from the Investment Coordinating Board of Gianyar Regency and 17 people of tourism workers.

b) Secondary data, i.e. supporting data and information obtained from the Sub-district of Ubud Bali Office.

\subsection{Research model specifications}

Budiono's Macroeconomic Theory in Gunma (2016). Basically, macroeconomic theory is a theory that discusses all events, phenomena or problems related to the economy as a whole or in a large scope. Macroeconomics is also a part of economics that focuses on the study of the working mechanism of a nation's economy as a whole. The purpose of macroeconomics is to understand and comprehend events or events around the economy and try to make a formula that becomes a solution to improve existing economic policies.

Rosenstein-Rodan and Nurkse's Balanced Growth Theory in Yunma (2006). This theory emphasizes that the economy is likely to develop if there is a good balance between the various sectors in the economy. With balanced growth this means that economic development will not succeed if the investment is limited to a certain "growing point" or sectors that are developing, because other sectors are closely related. Investment must be distributed to all sectors so as to expand the market between one sector and another. The closer interdependence between various sectors, the market will be stronger. To realize this theory, of course, must be supported by a large investment.

\subsection{Research Location}

The location of this research is in Sub-district of Ubud Bali by observing and mapping community activities in a measurable manner. The observation time as the object of analysis is the condition of 12 (twelve) months from January to December running in 2018. Consideration of the use of 2018 is taken to facilitate the recording of information on respondents, namely, the Investment Coordinating Board Sub-district of Ubud Bali.

\subsection{Research Instruments}

The instrument used in this research is descriptive research through literature surveys and field surveys and in-depth interviews. Interviews conducted are open-ended questions and closed-ended questions.

\subsection{Method of Data Analysis}

The analytical method used in this study includes several methods in accordance with the objectives of the study are as follows:

Macro Budiono's Economic Theory in Gunma (2016). Basically, macroeconomic theory is a theory that discusses all events, phenomena or problems related to the economy as a whole or in a large scope. Macroeconomics is also a part of economics that focuses on the study of the working mechanism of a nation's economy as a whole. The purpose of macroeconomics is to understand and comprehend events or events around the economy and try to make a formula that becomes a solution to improve existing economic policies. The government has published five economic policy packages throughout 2016, namely policy packages IX through XIV. Include policies in the industrial sector,

Sunariani, N. N., Maheswari, A. A. I. A., \& Pemayun, A. A. G. P. (2019). Grand investment of tourism sector effort to make many villas and hotels for expanding work opportunities on budgeting. International Research Journal of Management, IT and Social Sciences, 6(6), 43-49. https://doi.org/10.21744/irjmis.v6n6.755 
investment, increasing people's purchasing power, logistics, increasing exports, and national tourism. In fact, the policy is expected to reduce various obstacles to economic activity, both consumption, investment, production, and international trade. So that the domestic economy can grow better.

Indonesia's Center for Reform on Economics (CORE) economist explained that not all of the packages could be assessed for impact in a short time. Bearing in mind some of these policies are related to improving the business climate that has time lags for business actors. Moreover, the weak domestic and global demand has made the policy impact on domestic economic activities not significant. Some of the policy packages are not expected to have an effective impact, both in terms of technical implementation and in terms of the substance of the policy. Socialization to related parties is still low, while the implementation of policies by related ministries or institutions is also slow and the progress of the policy packages is difficult to evaluate because they do not have measurable time targets (Brata \& Pemayun, 2018).

In terms of the substance of policies, some policies are still partial and have not yet touched the substance of the problem to be solved. Policy package X which revised Presidential Regulation No. 39 of 2014 concerning the Negative Investment List with the aim of protecting entrepreneurs and providing certainty of restrictions on foreign share ownership.

Rosenstein-Rodan and Nurkse's Balanced Growth Theory in Yunma (2006). This theory emphasizes that the economy is likely to develop if there is a good balance between the various sectors in the economy. With balanced growth, this means that economic development will not succeed if investment is limited to a certain "growing point" or sectors that are developing, because other sectors are closely related. Investment must be distributed to all sectors so as to expand the market between one sector and another. The closer interdependence between various sectors, the market will be stronger. To realize this theory, of course, must be supported by a large investment (Arcana \& Wiweka, 2016).

The essence of the Rosenstein-Rodan formula is to overcome obstacles to economic development in developing countries and to push the economy toward progress requires a "massive push" or a comprehensive program that refers to a certain minimum investment amount. In emphasizing his arguments, Rosenstein-Rodan uses an analogy: "there are a minimum number of resources that must be provided if a development program is expected to succeed. Spurring an economy towards self-sufficiency seems a little like an airplane that will take off, there is a critical point of speed that must be passed before the aircraft can fly".

\section{Results and Discussions}

Budiono's Macroeconomic Theory in Gunma (2016). Implementing Macroeconomic policies coordinated by Bank Indonesia saw signs of economic improvement based on achieving the second quarter of 2016 growth that exceeded expectations. However, there are still a number of uncertainty factors in the global economy so that the Central Bank is hesitant to decide on easing monetary policy. Deputy Governor of Bank Indonesia Perry Warjiyo said Bank Indonesia must examine the risks and conditions of the financial markets to determine the direction of monetary policy going forward. Because, although economic growth in the country shows signs of strengthening, there is still a risk of the global economy. So the latest risk assessment and financial market outlook (Suniastha Amerta, 2017).

Bank Indonesia is still looking for the right time to relax its policies by taking into account two factors of the global economy. Is monetary easing in June to July the right time compared to November and December? First, financial market conditions face the risk of rising interest rates in the United States (US), namely the Fed Rate. Since the beginning of this year the US Central Bank has indicated it will again raise interest rates. But, until now the policy has not been implemented because the economic conditions have not improved. Second, the belief that economic growth has fundamentally improved. The consideration, there is still a risk of the impact of the exit of the UK from the European Union (Britain's Exit / Brexit) on the world economy and Indonesia as well as the Sub-district of Ubud Bali in particular. In addition, commodity prices are expected to remain under pressure from policy changes made by the Chinese government.

This causes exports to remain depressed until the end of the year because China is one of Indonesia's main trading partners. These two risk factors are the reasons Bank Indonesia does not intend to raise its projections of economic growth this year was 5.1 percent. Although the realization of economic growth in the second quarter of 2016 was above previous expectations, which amounted to 5.18 percent and overall in the first semester of 2016 grew 5.04 percent. There are still some uncertainties in the third and fourth quarters. Bank Indonesia is still reviewing the impact of the planned budget cuts of IDR. 133.8 trillion on the economy. The central bank estimates that the impact of the policy is not too large as long as the government does not cut productive spending, such as for infrastructure projects. Moreover, 
so far the absorption of government spending has always been below the target. If the budget cuts are followed by an increase in budget absorption, it will still be able to encourage economic growth. If the absorption (budget) reaches 90 to 95 percent, the effect is not much (on economic growth). Basically the economic development of a country aims to achieve the prosperity of the people of Ubud Bali Village through high economic growth and equitable distribution of income by creating employment-wide breadth. If related to investment, the more investment will require a lot of manpower, so it is very appropriate that if the investment is greater, a country's economy will grow and develop. Investment is a component of a large enough expenditure and is not easily used up, so large changes in investment will greatly affect demand (Pemayun \& Suderana, 2019).

Investment encourages capital accumulation, the addition of building stock and other equipment, will increase a nation's potential output and stimulate long-term economic growth. Job opportunities are closely related to the ability of companies to accommodate or absorb human resources in relation to the production process. If there are no people who can become entrepreneurs, the unemployed will increase in number. Developed and developing countries really expect Full Employment (full employment opportunity) is a situation that occurs in an economy characterized by all people who are able and willing to work, both employed and have the opportunity to work.

Full employment is indicated by the number of workers in the Sub-district of Ubud Bali or equal employment opportunities or can also exceed the number of available jobs or employment opportunities equal to or exceeding the number of people in the Sub-district of Ubud Bali looking for work. To increase domestic capital, the Indonesian government seeks foreign debt assistance, which is not bad, if it is natural. But if the amount is not fair, of course it will affect the stability of the national economy. This is related to risks that can occur if the government does not anticipate it. Foreign debt assistance will actually slow growth which is closely related to the substitution of foreign investment and savings, as well as the growing deficit of the country's balance of payments. Bearing in mind that Indonesia is still a developing country (Geria et al., 2018).

Rosenstein-Rodan and Nurkse's Balanced Growth Theory in Yunma (2006). Balanced development is a development that is carried out evenly for each region, in Gianyar, especially in the Sub-district of Ubud Bali so that each region gets equitable development for each population. Every population receives prosperity in the industrial sector and the agricultural sector. The need for balanced development is to ensure that the development does not face obstacles in obtaining facilities involving materials or goods for the implementation of development. According to RosensteinRoben's view, it is stated that balanced development is to create various types of industries which have an attachment to other developments so that each industry will obtain an external economy as a result of industrialization. While Nurkse's opinion is not much different from Rosenstein-Roben's opinion, Nurkse argues the need for balanced development, that is, development is carried out not only to benefit from the sale of goods or infrastructure but also to obtain markets for goods produced by various industries to be developed.

In their view that balanced development only emphasizes the demand side. This theory emphasizes that the economy is likely to develop if there is a good balance between various sectors in the economy. With balanced growth, this means that economic development will not succeed if the investment is limited to a specific growth point or developing sectors, because other sectors are closely related. Investment must be distributed to all sectors so as to expand the market between one sector and another. The closer interdependence between various sectors, the market will be stronger. To realize this theory, of course, must be supported by a large investment.

The balance of development in various sectors in the Ubud Bali Village such as the tourism industry sector with the agricultural sector, between the consumer goods industry and the capital goods industry, between the foreign sector and the domestic sector, and between the productive sector and the sector and infrastructure sector. In the end, this balanced development requires simultaneous and harmonious development in various economic sectors so that the whole sector will grow together. Therefore, a balance is needed between the demand side and the supply side.

The supply-side emphasizes the simultaneous development of all interrelated sectors and serves to increase the supply of goods. This supply-side includes the simultaneous and harmonious development of semi-finished goods, raw materials, energy resources, agriculture, irrigation, transportation. On the supply side it relates to providing greater employment opportunities for the people of Sub-district of Ubud Bali and increasing income so that demand for goods and services grows. This site relates to industries which are complementary in nature.

Besides this balanced development goals are carried out with a view to maintaining that the development process does not face obstacles such as (1) Obtaining raw materials, experts, energy resources, and facilities to transport production products to the market. (2) Acquiring markets for goods that have been and will be produced. If this way of working step by step will not encourage the economy to succeed in moving smoothly through the development trajectory. Therefore, a certain minimum investment level is an initial solution to get a good start. Thus Rosenstein-

Sunariani, N. N., Maheswari, A. A. I. A., \& Pemayun, A. A. G. P. (2019). Grand investment of tourism sector effort to make many villas and hotels for expanding work opportunities on budgeting. International Research Journal of Management, IT and Social Sciences, 6(6), 43-49. https://doi.org/10.21744/irjmis.v6n6.755 
Rodan, requires absolute minimum and economic externalities, namely: Minimum absolute conditions in the production function, minimum absolute requirements on-demand and minimal absolute requirements on savings inventories. Stated by Rosenstein-Rodan, the existence of large-scale industrial development is considered to be able to create three types of economic externalities, namely first, Externalities caused by market expansion. Second, Externalities are created because industrial locations are close to one another. Third, the externalities created by the presence of other industries in the economy.

Based on the description above, it can be concluded that balanced development aims to equalize the existing development in the Sub-district of Ubud Bali for the welfare of the community. With balanced growth, this means that economic development will not succeed if investment is limited to a specific growth point or developing sectors, because other sectors are closely related. Investment must be distributed to all sectors so as to expand the market between one sector and another.

\section{Findings}

First, investment encourages capital accumulation, the addition of building stock and other equipment, will increase a nation's potential output and stimulate long-term economic growth.

Second, with balanced growth that economic development will not succeed if the investment is limited to a certain growth point or growing sectors, because other sectors are closely related. Investment must be distributed to all sectors so as to expand the market between one sector and another.

\section{Conclusion}

Based on the discussion above, several conclusions can be made including:

First, the macroeconomic situation of Bali and the Sub-district of Ubud Bali in particular by seeing signs of economic improvement based on achieving the second quarter of 2016 growth that exceeded expectations. The more investment will require a lot of manpower so that it is appropriate that the greater the investment, the economy of a country will grow and develop. Investment is a component of a large enough expenditure and is not easily used up, so large changes in investment will greatly affect demand. Investment encourages capital accumulation, the addition of building stock and other equipment, will increase a nation's potential output and stimulate long-term economic growth. Employment opportunities are closely related to the ability of companies to accommodate or absorb human resources in the Subdistrict of Ubud Bali in relation to the production process.

Second, the balance of development in various sectors in the Sub-district of Ubud Bali such as the tourism industry sector with the agricultural sector, between the consumer goods industry and the capital goods industry, between the foreign sector and the domestic sector, and between the productive sector and the sector and the infrastructure sector. In the end, this balanced development requires simultaneous and harmonious development in various economic sectors so that the whole sector will grow together. Therefore, a balance is needed between the demand side and the supply side. The supply-side emphasizes the simultaneous development of all interrelated sectors and serves to increase the supply of goods. This supply-side includes the simultaneous and harmonious development of semi-finished goods, raw materials, energy resources, agriculture, irrigation, transportation. On the supply side it relates to providing greater employment opportunities for the people of Sub-district of Ubud Bali and increasing income so that demand for goods and services grows. This site relates to industries which are complementary in nature.

\section{Conflict of interest statement}

The authors declared that they have no competing interest.

\section{Statement of authorship}

The authors have a responsibility for the conception and design of the study. The authors have approved the final article.

\section{Acknowledgments}

We thank the editor of IRJMIS for their valuable time, support and advice. 


\section{References}

Alexander, G. E., DeLong, M. R., \& Strick, P. L. (1986). Parallel organization of functionally segregated circuits linking basal ganglia and cortex. Annual review of neuroscience, 9(1), 357-381.

Amerta, I. M. S., Sara, I. M., \& Bagiada, K. (2018). Sustainable tourism development. International Research Journal of Management, IT and Social Sciences, 5(2), 248-254.

Arcana, K. T. P., \& Wiweka, K. (2016). Educational tourism's product strategy at batur global geopark, Kintamani, Bali. International Research Journal of Management, IT and Social Sciences, 3(7), 43-52.

Arliman, L. (2018). Peranan Metodologi Penelitian Hukum di Dalam Perkembangan Ilmu Hukum di Indonesia. Soumatera Law Review, 1(1), 112-132.

Bakhri, S. (2018). Minat Mahasiswa Dalam Investasi Di Pasar Modal. Al-Amwal: Jurnal Ekonomi dan Perbankan Syari'ah, 10(1), 146-157.

Brata, I. B., \& Pemayun, A. G. P. (2018). Human Resource Competency Tourism Bali together with ASEAN Economic Community. International Research Journal of Management, IT and Social Sciences, 5(2), 186-194.

Geria, A. A. G. A., Maheswari, A. I. A., \& Pemayun, A. A. G. P. (2018). Social media as promotion trend for increasing tourist visit towards digital era. International Journal of Social Sciences and Humanities, 2(3), 86-94. https://doi.org/10.29332/ijssh.v2n3.204

Pemayun, A. A. G. P., \& Suderana, I. W. (2019). Shifting social and economic structural community: rapid development of tourism sector. International Journal of Social Sciences and Humanities, 3(1), 115-124. https://doi.org/10.29332/ijssh.v3n1.271

Suniastha Amerta, I. M. (2017). The role of tourism stakeholders at Jasri tourism village development, Karangasem regency. International Journal of Social Sciences and Humanities, 1(2), $20-28$. https://doi.org/10.29332/ijssh.v1n2.32

Suwandi, K. (2011). Panduan Cerdas Investasi, Reksa Dana, Saham, Stock Option, Valas, Emas.

Wisudawati, N. N. S., \& Maheswari, A. I. A. (2018). Potential of Silver Craft Product through to Community-Based for Tourism Sustainability in Celuk Village. International Research Journal of Management, IT and Social Sciences, 5(1), 9-15.

Yahya, S., \& Goh, W. K. (2002). Managing human resources toward achieving knowledge management. Journal of knowledge management, 6(5), 457-468.

Yunma, H. (2006). Characteristics and causes of snow disaster-a case study of southern Qinghai. Journal of Further Education of Shaanxi Normal (Xi'an), 23(3), 119-122.

Sunariani, N. N., Maheswari, A. A. I. A., \& Pemayun, A. A. G. P. (2019). Grand investment of tourism sector effort to make many villas and hotels for expanding work opportunities on budgeting. International Research Journal of Management, IT and Social Sciences, 6(6), 43-49. https://doi.org/10.21744/irjmis.v6n6.755 